\title{
Carcass Traits and Immune Response of Broiler Chickens Fed Dietary L-Carnitine, Coenzyme $Q_{10}$ and Ractopamine

\section{-Author(s)}

\section{Asadi $\mathrm{H}^{\prime}$ \\ Sadeghi AA' \\ Eila N ${ }^{\text {III }}$}

Aminafshar $\mathrm{M}^{\prime}$

Department of Animal Science, Faculty of Agriculture, Tehran Science and Research Branch, Islamic Azad University, Tehran, Iran Department of Animal Science, Faculty of Agriculture, Karaj Branch, Islamic Azad University, Karaj, Iran

\section{Mail Address}

Corresponding author e-mail address Ali Asghar Sadeghi

Department of Animal Science, Science and Research Branch, Islamic Azad University,

Tehran, Iran.

Tel: $\quad$ +989195579663

Email: a.sadeghi@srbiau.ac.ir

\section{-Keywords}

Coenzyme Q10; L-carnitine; Ractopamine; Broiler chicken.

\section{ABSTRACT}

This study was conducted to evaluate the effects of coenzyme $\mathrm{Q}_{10}, \mathrm{~L}$-carnitine and ractopamine supplementation, alone and in combinations, on carcass traits and immune response of broiler chickens. Five hundred and twelve one-day-old Ross 308 male broiler chickens were randomly allocated into eight treatments with four replicates each. A $2 \times 2 \times 2$ factorial arrangement was applied, with two levels of coenzyme $Q_{10}(0$ and $40 \mathrm{mg} / \mathrm{kg}$ ), two levels of L-carnitine (0 and 200 $\mathrm{mg} / \mathrm{kg}$ ) and two levels of ractopamine ( 0 and $10 \mathrm{mg} / \mathrm{kg}$ ). The birds were reared until day 42 of age under standard conditions. Blood samples were collected at the end of grower and finisher periods from the wing vein. Four birds per group were sacrificed at day 42 of age. Except for carcass yield, other carcass traits were not significantly affected ( $p>0.05$ ) by different levels of coenzyme $Q_{10}, L$-carnitine, or ractopamine. Immune response parameters were significantly $(p<0.05)$ different between the treatments. The lowest antibody titers against Newcastle disease virus and relative spleen weight were observed in control group. The results of this study suggest that addition of coenzyme $Q_{10}$ and L-carnitine to broiler diets has benefit effect on immune response of broiler chickens.

\section{INTRODUCTION}

Physiological additives aid the normal development of physiological functions (Hassan et al., 2011). As early as 1963, beta-adrenergic agonists have been used in broiler diets (Cunning, 1963). The dietary administration of the beta-adrenergic agonist ractopamine, a potent growth promoter, has been shown to increase protein accretion and decrease fat deposition in turkeys (Wellenreiter \& Tonkinson, 1990). Various beta-adrenergic agonists have been shown to be capable of improving weight gain when added to the feed of domestic species. The feed additive ractopamine is a beta-adrenergic agonist licensed for use in cattle and swine diets by the US Food and Drug Administration in 2003. The positive effects of beta-adrenergic agonists on the performance of meat-producing animals, including poultry, are well documented in several experiments (Yousefi et al., 2011).

Coenzyme Q (2,3-dimethoxy, 5-methyl, 6-polyisoprene parabenzoquinone) is present in all membranes of cell. Ubiquinone or coenzyme $\mathrm{Q}_{10}$ is a vitamin - like substance which is found in small amounts in a wide variety of foods and is synthesized in all tissues. Ubiquinone is the coenzyme of at least three mitochondrial enzymes (complexes 1, 2 and 3). Mitochondrial enzymes of the oxidative phosphorylation pathway are essential for the production of the high oxidative energy phosphate containing compound, adenosine-tri-phosphate (ATP), upon which all cellular function depend (Ahmad et al., 2010). Coenzyme $Q_{10}$ acts as a non-specific stimulant of the immune host defense system. Coenzyme 
$\mathrm{Q}_{10}$ has been shown to protect experimental animals against tumor growth and to enhance the immunity to viruses. In a study with eight chronically-ill human patients, the administration of coenzyme $Q_{10}$ at 60 $\mathrm{mg} /$ day was associated with significant increases in serum levels of immunoglobulin $G$ after 27-98 day of treatment (Folkers, 1982). The results of a study showed that the dietary combination of coenzyme $\mathrm{Q}_{10}$ and L-carnitine reduce packed cell volume and ascites mortality in broiler (Asadi et al., 2013).

The chemical structure of L-carnitine (B-hydroxy $\gamma$-trimethyl amino butyrate) was elucidated in 1927. Carnitine was synthesized in vivo from lysine and methionine in the kidney and testes (rat), skeletal muscle (sheep), brain (man), and liver in all mammals. During carnitine synthesis, lysine provides the carbon chain and the nitrogen atom, while methionine provides the methyl groups (Arsalan, 2006). The major role of L-carnitine appears to be the transport of longchain fatty acids into the mitochondria for B-oxidation. In addition to its role in the oxidation of fatty acids, L-carnitine was shown to exhibit immunomodulatory effects. Mast et al. (2000) showed that dietary $\mathrm{L}$-carnitine supplementation increased the production of antigen-specific immunoglobulin $G$ in broiler chickens. This amine is present at high concentrations in the lymphocytes, where it is involved in apoptosis inhibition and in the proliferative response to mitogens (Desimone et al., 1994).

The aim of this experiment was to investigate the effects of the dietary supplementation of coenzyme $\mathrm{Q}_{10}$, L-carnitine and ractopamine, individually and in combination, on the carcass traits and immune parameters of broiler chickens.

\section{MATERIALS AND METHODS}

In this study, 521 one-day-old male Ross 308 broilers were obtained from a commercial hatchery. Birds were randomly distributed into eight treatment groups with four replicates of 16 chicks each. The experiment was conducted according to a completely randomized design in a $2 \times 2 \times 2$ factorial arrangement, consisting of two levels of ractopamine $(0,10 \mathrm{mg} / \mathrm{kg})$, two levels of coenzyme $Q_{10}(0,40 \mathrm{mg} / \mathrm{kg})$, and two levels of L-carnitine $(0,200 \mathrm{mg} / \mathrm{kg})$. Treatments included $T_{1}$ : basal diet (control), $T_{2}$ : basal diet+ ractopamine, $T_{3}$ : basal diet +coenzyme $\mathrm{Q}_{10^{\prime}} \mathrm{T}_{4}$ : basal diet + L-carnitine, $\mathrm{T}_{5}$ : basal diet + ractopamine + coenzyme $\mathrm{Q}_{10^{\prime}} \mathrm{T}_{6}$ : basal diet + ractopamine + L-carnitine, $\mathrm{T}_{7}$ : basal diet +coenzyme $\mathrm{Q}_{10}+\mathrm{L}$-carnitine, and $\mathrm{T}_{8}$ : basal diet + ractopamine +coenzyme $\mathrm{Q}_{10}+\mathrm{L}$-carnitine.
The diets were based on corn and soybean meal, formulated according to the recommendations of the Ross 308 manual, and offered as mash. The feedstuffs and nutrient composition of the starter (days 1-10), grower (days 11-24), and finisher (days 25-42) are presented in Table 1.

Table 1 - Composition and nutrient levels of the starter, grower and finisher diets

\begin{tabular}{|c|c|c|c|}
\hline Ingredients (\%) & $\begin{array}{l}\text { Starter } \\
(1-10)\end{array}$ & $\begin{array}{l}\text { Grower } \\
(11-24)\end{array}$ & $\begin{array}{l}\text { Finisher } \\
(25-42)\end{array}$ \\
\hline Corn grain & 52.28 & 51.80 & 59.00 \\
\hline Soybean meal (44\% CP) & 36.37 & 34.90 & 28.20 \\
\hline Soybean oil & 3.90 & 5.07 & 4.60 \\
\hline Fish meal & 3.07 & 5.00 & 5.00 \\
\hline Di-calcium phosphate & 2.09 & 1.19 & 1.10 \\
\hline Oyster shell & 0.77 & 0.89 & 0.91 \\
\hline Vitamin/mineral premix ${ }^{*}$ & 0.60 & 0.50 & 0.50 \\
\hline Dl- methionine & 0.33 & 0.24 & 0.22 \\
\hline L-Lysine & 0.21 & 0.11 & 0.13 \\
\hline Salt & 0.20 & 0.17 & 0.20 \\
\hline $\mathrm{NaHCO}_{3}$ & 0.11 & 0.12 & 0.10 \\
\hline L- Threonine & 0.07 & 0.01 & 0.04 \\
\hline \multicolumn{4}{|c|}{ Calculated nutrient contents (\%) } \\
\hline $\mathrm{ME}(\mathrm{kcal} / \mathrm{kg})$ & 3025 & 3150 & 3198 \\
\hline Crude protein & 22.4 & 22.4 & 20.0 \\
\hline Calcium & 1.00 & 0.90 & 0.87 \\
\hline Available phosphorus & 0.50 & 0.45 & 0.43 \\
\hline Methionine & 0.68 & 0.57 & 0.52 \\
\hline Methionine+cystine & 1.03 & 0.95 & 0.87 \\
\hline Lysine & 1.41 & 1.34 & 1.20 \\
\hline Threonine & 0.94 & 0.88 & 0.82 \\
\hline
\end{tabular}

*Supplied per kg of diet:

Vitamin A 12000IU, Vitamin E 10mg, Vitamin D 2200IU, niacin 35mg,

D-pantothenic acid $12 \mathrm{mg}$, riboflavin $3.63 \mathrm{mg}$, pyridoxine $3.5 \mathrm{mg}$, thiamine $2.4 \mathrm{mg}$, folic acid $1.4 \mathrm{mg}$, biotin $0.15 \mathrm{mg}$, Vitamin B $0.03 \mathrm{mg}$, Manganese $60 \mathrm{mg}$, Zinc $40 \mathrm{mg}$, Iron 1280mg, Copper 8mg, lodine 0.3mg, Selenium $0.2 \mathrm{mg}$

Birds were housed in an environmentally-controlled room. House temperature was initially maintained at $32{ }^{\circ} \mathrm{C}$ and then gradually reduced to $23-24{ }^{\circ} \mathrm{C}$ for the remaining of the experimental period. Air relative humidity was maintained at $65 \%$. A continuous lighting program was applied for the first three days, after which a 23-h light: 1-h dark cycle was provided. Feed and fresh water were available ad libitum.

Feed was withdrawn three hours before slaughter. At the end of experiment ( 6 weeks), one bird per pen, which body weight was nearest to the average in the pen, was sacrificed by severing the jugular vein Carcass and edible parts, including heart and liver, yields were calculated relative to body weight at sacrifice.

Birds were individually vaccinated using a commercial Newcastle disease virus (NDV) vaccine on days $8\left(B_{1}\right)$ and 18 (LaSota). Blood samples of one bird per replicate were collected from the wing vein at days 24 and 42 of 
age. Sera were separated and stored at $-20{ }^{\circ} \mathrm{C}$ before analysis. Antibody titers against Newcastle disease were measured by hemagglutination-inhibition test (Allan and Gough, 1974). Antibody titer values were $\log _{2}(\mathrm{x})$ transformed before statistical analysis.

Blood samples were collected from the wing vein in sterile test tubes containing anticoagulant (sodium citrate) at the end of experimental period to determine white blood cell count (WBC) and the absolute numbers of each leukocyte type.

Statistical analysis was performed using SPSS 20 for Windows. Firstly, the normality of data distribution was verified using the Kolmogorov-Smirnov test. Data were subjected to analysis of variance using the GLM (general linear model) procedure, means were compared by Duncan's Multiple Range test. Statistical significance was accepted when $p<0.05$.

\section{RESULTS AND DISCUSSION}

The effect of coenzyme $Q_{10}$, ractopamine, and L-carnitine on carcass traits are presented in Table 2. As shown in Table 2, the dietary supplementation of these compounds had no effect on breast yield, thigh yield, or heart and liver percentages. This finding was in agreement with report of Farhangfar et al. (2010), who did not detect any effect of coenzyme $Q_{10}$ at level of $20 \mathrm{mg} / \mathrm{kg}$ of feed on carcass, thighs, or breast yields. Honda et al. (2010) also showed that liver weight was not influenced by coenzyme $\mathrm{Q}_{10}$ supplementation. In agreement with our findings, Akbariazad et al. (2010) observed that the use of L-carnitine in broiler chicks had no significant effects on carcass traits. In contrast, Kidd et al. (2009) verified a significant increase in the leg yield of broilers fed L-carnitine. These differences probably are related to the level of L-carnitine supplementation, broiler sex, and composition of experimental diet.

Among the eight treatments, the control broilers presented the lowest carcass yield, which was significantly relative to treatment 5 (ractopamine + coenzyme $\mathrm{Q}_{10}$ ), treatment 6 (ractopamine+ L-carnitine), and treatment 8 (ractopamine + coenzyme $\mathrm{Q}_{10}+\mathrm{L}$-carnitine) The higher carcass observed in the present study is consistent with the findings of Moslemipur et al. (2012), with the addition of terbutaline, a beta-adrenergic antagonist to broiler diets. Differences in broiler sex, type and level of beta-adrenergic agonist, and diet compositions may explain the differences between the results obtained in our experiment and in other studies.

Newcastle antibody titers determined at days 24 and 42 of age, white blood cell (WBC) counts, spleen relative weight, and heterophil to lymphocyte ratio are summarized in Table 3. The results showed that WBC counts were not affected by ractopamine, coenzyme $\mathrm{Q}_{10}$ or L-carnitine supplementation. These results are in agreement with an earlier report by Akbariazad et al. (2010), who showed that the dietary inclusion of L-carnitine at levels of 125 and 250 ppm had no significant effect on the WBC count of broilers. On the other hand, Karadeniz et al. (2008) found an

Table 2 - Effects of supplemental dietary ractopamine, coenzymeQ ${ }_{10}$ and L-carnitine on carcass traits of broiler chickens. (mean \pm standard deviation)

\begin{tabular}{|c|c|c|c|c|c|c|c|}
\hline \multicolumn{3}{|c|}{ Parameter } & Carcass (\%) & Thigh (\%) & Breast (\%) & Heart (\%) & Liver (\%) \\
\hline \multicolumn{8}{|c|}{ Ractopamine $(\mathrm{mg} / \mathrm{kg})$} \\
\hline \multicolumn{3}{|c|}{0} & $73.4 \pm 0.9^{b}$ & $29.4 \pm 0.9$ & $35.1 \pm 1.2$ & $0.57 \pm 0.09$ & $2 \pm 0.25$ \\
\hline \multicolumn{3}{|c|}{10} & $74.4 \pm 1.1^{a}$ & $29.9 \pm 0.9$ & $34.3 \pm 1.2$ & $0.6 \pm 0.06$ & $2 \pm 0.18$ \\
\hline \multicolumn{8}{|c|}{ Coenzyme $\mathrm{Q}_{10}(\mathrm{mg} / \mathrm{kg})$} \\
\hline \multicolumn{3}{|c|}{0} & $73.6 \pm 1.2$ & $29.6 \pm 0.8$ & $34.7 \pm 1.3$ & $0.57 \pm 0.08$ & $1.95 \pm 0.17$ \\
\hline \multicolumn{3}{|c|}{40} & $74.2 \pm 1.07$ & $29.7 \pm 1$ & $34.7 \pm 1.2$ & $0.61 \pm 0.07$ & $2.1 \pm 0.23$ \\
\hline \multicolumn{8}{|c|}{ L-caraitine (mg/kg) } \\
\hline \multicolumn{3}{|c|}{0} & $73.8 \pm 1.19$ & $29.4 \pm 0.9$ & $34.4 \pm 1.16$ & $0.58 \pm 0.07$ & $2.1 \pm 0.23$ \\
\hline \multicolumn{3}{|c|}{200} & $74.1 \pm 1.2$ & $29.9 \pm 0.9$ & $35 \pm 1.25$ & $0.6 \pm 0.09$ & $2 \pm 0.2$ \\
\hline \multicolumn{8}{|c|}{ RXQ10XL-C } \\
\hline 0 & 0 & 0 & $72.8 \pm 0.5^{b}$ & $29.5 \pm 0.4$ & $35.03 \pm 0.4$ & $0.56 \pm 0.08$ & $1.97 \pm 0.18$ \\
\hline 10 & 0 & 0 & $74.1 \pm 1.3^{\mathrm{ab}}$ & $29.8 \pm 0.3$ & $33.4 \pm 1.1$ & $0.55 \pm 0.03$ & $1.99 \pm 0.6$ \\
\hline 0 & 40 & 0 & $73.6 \pm 1.4^{a b}$ & $29.9 \pm 0.9$ & $34.6 \pm 1.6$ & $0.6 \pm 0.09$ & $2.12 \pm 0.33$ \\
\hline 0 & 0 & 200 & $73.4 \pm 0.75^{a b}$ & $29.1 \pm 1$ & $35.3 \pm 0.9$ & $0.54 \pm 0.12$ & $1.9 \pm 0.29$ \\
\hline 10 & 40 & 0 & $74.7 \pm 0.61^{\mathrm{a}}$ & $29.8 \pm 1.5$ & $34.2 \pm 0.25$ & $0.6 \pm 0.07$ & $2.19 \pm 0.26$ \\
\hline 10 & 0 & 200 & $74.2 \pm 1.8^{a}$ & $30.2 \pm 1$ & $34.8 \pm 1.7$ & $0.63 \pm 0.05$ & $1.94 \pm 0.1$ \\
\hline 0 & 40 & 200 & $73.7 \pm 1.06^{a b}$ & $29.3 \pm 0.5$ & $35.1 \pm 1.8$ & $0.58 \pm 0.08$ & $2.11 \pm 0.2$ \\
\hline 10 & 40 & 200 & $74.7 \pm 0.8^{a}$ & $29.6 \pm 0.9$ & $35 \pm 0.96$ & $0.63 \pm 0.08$ & $2 \pm 0.16$ \\
\hline
\end{tabular}

Values with different superscripts in the same column for each section are significantly different $(p<0.05)$. 
Table 3 - Effects of supplemental dietary ractopamine, coenzymeQ ${ }_{10}$ and L-carnitine on immune response of broiler chickens. (mean \pm standard deviation)

\begin{tabular}{|c|c|c|c|c|c|c|c|}
\hline \multicolumn{3}{|c|}{ Parameter } & $\mathrm{WBC}^{1}(\mathrm{x} / \mu \mathrm{l})$ & $\begin{array}{l}\text { Heterophil/ } \\
\text { Lymphocyte }\end{array}$ & $\begin{array}{c}\text { Newcastle titer } \\
\text { (day 24) } \\
\text { Log } 2 \\
\end{array}$ & $\begin{array}{c}\text { Newcastle titer } \\
(\text { day } 42) \\
\log 2 \\
\end{array}$ & $\begin{array}{c}\text { Spleen relative weight } \\
(\%)\end{array}$ \\
\hline \multicolumn{8}{|c|}{ Ractopamine (mg/kg) } \\
\hline \multicolumn{3}{|c|}{0} & $26350 \pm 4026$ & $0.44 \pm 0.06$ & $2.61 \pm 0.41$ & $2.3 \pm 0.46$ & $0.121 \pm 0.029$ \\
\hline \multicolumn{3}{|c|}{10} & $26356 \pm 3048$ & $0.46 \pm 0.08$ & $2.57 \pm 0.2$ & $2.2 \pm 0.35$ & $0.13 \pm 0.018$ \\
\hline \multicolumn{8}{|c|}{ Coenzyme $\mathrm{Q}_{10}(\mathrm{mg} / \mathrm{kg})$} \\
\hline \multicolumn{3}{|c|}{0} & $27244 \pm 3258$ & $0.44 \pm 0.05$ & $2.47 \pm 0.32^{b}$ & $2.13 \pm 0.4$ & $0.119 \pm 0.024$ \\
\hline \multicolumn{3}{|c|}{40} & $25462 \pm 3632$ & $0.46 \pm 0.08$ & $2.71 \pm 0.27^{a}$ & $2.37 \pm 0.38$ & $0.133 \pm 0.022$ \\
\hline \multicolumn{8}{|c|}{ L-caraitine (mg/kg) } \\
\hline \multicolumn{3}{|c|}{0} & $26256 \pm 2474$ & $0.47 \pm 0.07$ & $2.5 \pm 0.37$ & $2.12 \pm 0.42$ & $0.119 \pm 0.024$ \\
\hline \multicolumn{3}{|c|}{200} & $26450 \pm 4400$ & $0.43 \pm 0.06$ & $2.67 \pm 0.23$ & $2.38 \pm 0.36$ & $0.133 \pm 0.022$ \\
\hline \multicolumn{8}{|c|}{ RXQ10XL-C } \\
\hline 0 & 0 & 0 & $27125 \pm 3492$ & $0.42 \pm 0.02^{b}$ & $2.13 \pm 0.37^{b}$ & $1.87 \pm 0.36^{b}$ & $0.09 \pm 0.014^{b}$ \\
\hline 10 & 0 & 0 & $25775 \pm 1300$ & $0.42 \pm 0.07^{b}$ & $2.45 \pm 0.15^{\mathrm{ab}}$ & $1.89 \pm 0.21^{b}$ & $0.13 \pm 0.018^{a}$ \\
\hline 0 & 40 & 0 & $26275 \pm 1676$ & $0.49 \pm 0.05^{\mathrm{ab}}$ & $2.87 \pm 0.37^{a}$ & $2.58 \pm 0.5^{\mathrm{a}}$ & $0.125 \pm 0.026^{a}$ \\
\hline 0 & 0 & 200 & $26550 \pm 5026$ & $0.44 \pm 0.07^{b}$ & $2.73 \pm 0.29^{a}$ & $2.4 \pm 0.4^{\mathrm{ab}}$ & $0.125 \pm 0.023^{a}$ \\
\hline 10 & 40 & 0 & $25850 \pm 3518$ & $0.55 \pm 0.06^{a}$ & $2.57 \pm 0.19^{a}$ & $2.16 \pm 0.18^{\mathrm{ab}}$ & $0.132 \pm 0.017^{a}$ \\
\hline 10 & 0 & 200 & $29525 \pm 1857$ & $0.48 \pm 0.02^{\mathrm{ab}}$ & $2.57 \pm 0.19^{a}$ & $2.36 \pm 0.33^{\mathrm{ab}}$ & $0.132 \pm 0.02^{\mathrm{a}}$ \\
\hline 0 & 40 & 200 & $25450 \pm 6231$ & $0.41 \pm 0.08^{b}$ & $2.74 \pm 0.2^{\mathrm{a}}$ & $2.36 \pm 0.33^{\mathrm{ab}}$ & $0.147 \pm 0.02^{\mathrm{a}}$ \\
\hline 10 & 40 & 200 & $24275 \pm 2995$ & $0.4 \pm 0.05^{b}$ & $2.67 \pm 0.3^{a}$ & $2.4 \pm 0.4^{\mathrm{ab}}$ & $0.127 \pm 0.02^{\mathrm{a}}$ \\
\hline
\end{tabular}

Values with different superscripts in the same column for each section are significantly different $(p<0.05)$. ${ }^{1} \mathrm{WBC}$, White blood cell.

increase in WBC counts when adding L-carnitine to broiler diets. These differences are probably due to the levels of L-carnitine supplementation, broiler sex, and composition of the experimental diets. Results of Table3 indicate that the spleen relative weight of control broilers was significantly lower than that of the other groups $(p<0.05)$. The spleen is a secondary lymphoid organ that filters bloodborne antigens, and it is a major site of immune response. These results agree with those of Hassan et al. (2011), who obtained higher spleen relative weight when adding $100 \mathrm{mg}$ L-carnitine/kg diet compared with the control group.

Antibody titers against Newcastle disease at day 24 of age were significantly higher when coenzyme $\mathrm{Q}_{10}$ was added to the diet $(\mathrm{p}<0.05)$. Tanner (1992) observed that coenzyme $Q_{10}$ protected animals against tumor growth and enhanced their immunity against viruses. Many experiments indicated that coenzyme Q is an important component for the optimal function of immune system (Lookwood et al., 1995). Among the eight treatment groups, the control group presented the lowest antibody titers against Newcastle. These results indicate that use of $\mathrm{L}$-carnitine had positive effect on the immune response. Similar results were obtained by Akabariazad et al. (2010), who reported that antibody titers against Newcastle disease measured in 350-day-old broilers significantly increased by dietary L-carnitine supplementation. Mast et al. (2000) also found that dietary L-carnitine supplementation (100 $\mathrm{mg} / \mathrm{kg}$ ) appeared to be beneficial in enhancing specific humoral response in broiler chickens. Geng et al. (2007) also demonstrated that serum IgG titers increased when L-carnitine was individually supplemented, and that lysozyme activity increased when L-carnitine and Coenzyme $\mathrm{Q}_{10}$ were added together to broiler diets. In contrast, Kheirkah et al. (2009) did not find any differences in anti-NDV or anti-SRBC titers in broiler chickens fed with diets supplemented with L-carnitine at $100 \mathrm{mg} / \mathrm{kg}$ and $200 \mathrm{mg} / \mathrm{kg}$. This difference probably is related to broiler genetic strain, day of blood collection, and composition of experimental diets.

The results of the present study suggest that dietary supplementation of coenzyme $\mathrm{Q}_{10}$ individually or combined with L-carnitine has positive effects on the humoral immune response of broilers. In addition, dietary ractopamine supplementation significantly improved carcass yield.

\section{ACKNOWLEDGEMENTS}

The authors are grateful to the Islamic Azad University for research funding support. We also thank all staffs of the Poultry unit for their assistance in the care and feeding of broilers used in this study.

\section{REFERENCES}

Ahmed AS, Faddah L, Abdelbaky A, Bayoumi A. Protective effect of L-carnitine and coenzymeQ ${ }_{10}$ On CCL4 induced liver injury in rats. Scientia Pharmaceutica 2010;78:881-896. 
Akbariazad G, Haghighi- Khoshkoo P, lla N, Moayer F, Dehghan- Nayeri $\mathrm{H}$. The effects of dietary L-carnitine supplementation on overall performance, carcass traits, blood components and immune response in broiler chickens. Journal of Veterinary Clinical Research 2010;1:7-17.

Allan WH, Gough RE. A standard haemagglutiation inhibition test for Newcastle disease. A comparison of macro and micro methods. Veterinary Records 1974;95:120 -123.

Arsalan C. L-carnitine and its use as a feed additive in poultry feeding a review. Revue de Medicine Veterinaire 2006;15:134-142.

Asadi $H$, Sadeghi AA, Eila $N$, Aminafshar $M$. The effects of ractopamine,coenzyme $\mathrm{Q}_{10}$ and $\mathrm{L}$-carnitine supplementation, Individual or in combination, on the hematological parameters of broiler chickens. World Applied Sciences Journal 2013;21:69-72.

Cunning HM. Effects of epinephrine, norepinephrine and nicotine on growth and carcass composition of chicks. Poultry Science 1963;42:1197.

Desimone C, Famularo G, Tzantzoglou S, Trinchieri V, Moretti S, Sorice F. Carnitine depletion in peripheral blood mononuclear cells from patients with A1DS : effect of oral L- carnitine. AIDS 1994;8:655-660.

Farhangfar B, Hoseini SA, Zarei A, Lotfollahian H. Effect of feed restriction and diets contained coenzyme $Q_{10}$ on performance and carcass traits of broiler. Animal Science and Research Journal 2010;7:53-64.

Folkers K, Shizukuishi S, Takemura K, Drzewoski J, Richardson P, kuzell WC. Increase in levels of $\mathrm{IgG}$ in serum of patients treated with coenzyme $Q_{10}$. Research Communications in Chemical Pathology and Pharmacology 1982;38:335-338.

Geng A, Li B, Guo Y. Effects of dietary L-carnitine and coenzymeQ ${ }_{10}$ at different supplemental ages on growth performance and some immune response in ascites-susceptible broilers. Archives of Animal Nutrition 2007;61:50-60.

Hassan MS, Youssef SF, EL-bahy NMA. Effects of L-carnitine and ascorbic acid supplementation on productive, reproductive, physiological and immunological performance of golden montazeh laying hens. Egyptian Poultry Science 2011;31:557-578.

Honda K, Kamisoyama H, Motoori T, Hosegawa SH. Effect of dietary coenzyme $\mathrm{Q}_{10}$ on cholesterol metabolism in growing chickens. Japan Poultry Science 2010;47:41-47.
Janssens GPJ, Mast J, Goddeeris BM, Cox E, Hasta M, Dewilde ROM. Enhanced specific antibody response to bovine serum albumin in pigeons due to L-carnitine supplementation. British Poultry Science 2000;41:448-453.

Karadenize A, Simsek N, Cakir S. Haematological effects of dietary Lcarnitine supplementation in broiler chicken. Revue de Medicine Veterinaire 2008:159:437-443.

Kheirkhah AR, Rahimi SH, Torshizi MA, Malekmohamadi H. Effect of different levels of L-carnitine supplementation in broiler breeders and their progeny's diets on performance, blood factors, carcass characteristics and immune system of broiler. Journal of Veterinary Research 2009;64:283-289.

Kidd MT, Gillbert J, Corzo A, Virden WS, Wood-worth C. Dietary L- carnitine influences broiler thigh yield. Asian-Austaralian Journal of Animal Science 2009;22:681-685.

Lookwood K, Moesgaard S, Yamamoto T, Folkers K. Progress on therapy of breast cancer with vitamin $Q_{10}$ and the regression of metastases. Biochemical and Biophysical Research Communications 1995;212:172177.

Mast J, Buyse J, Goodeerie BM. Dietary L-carnitine supplementation increase antigen- specific immunoglobulin $G$ production in broiler chickens. British Journal of Nutrition 2000;83:161-166.

Moslemipur F, Adabi ShG, Davoodi J, Kamali MA. Effect of different levels of terbutaline on performance, carcass traits blood metabolites in broiler chicks. Veterinary Journal 2012;91:43-52.

Tanner HA. Energy transformations in the biosynthesis of the immune system:their relevance to the progression and treatment of aids. Medical Hypotheses 1992;38:315 -321.

Wellenreiter RH, Tonkinson LV. Effects of ractopamine hydrochloride on growth performance of turkeys. Poultry Science 1990;69(1):142.

Yousefi J, Maherisis N, Telli A, Hatefinezhad K, Eshartkhah B, Saber SN, Effect of salbutamol (a beta- adrenergic agonist) on growth performance of broiler chickens. Annals of Biological Research 2011;2:500-505. 
